Research Paper

\title{
Law Enforcement of Criminal Forests and Land Fire in Kabupaten Indragiri Hilir, Province of Riau
}

\section{Rizana $^{1}$}

${ }^{1}$ Faculty of Law, Universitas Lancang Kuning, Indonesia.

Article History

Received:

19.01 .2020

Revised:

25.02.2020

Accepted:

24.03.2020

*Corresponding Author:

Rizana

Email:

rizana@unilak.ac.id

This is an open access article, licensed under: $\mathrm{CC}-\mathrm{BY}-\mathrm{SA}$
Abstract: Forest and land fires are not a rare phenomenon in Indonesia, especially in Riau Province. This research aims to explain the law enforcement of forest and land fire crimes in District of Indragiri Hilir, Riau Province. The method used in this research is socio-legal research. Based on Article 50 Paragraph (3) Letter d of Law Number 41 of 1999 it is stated that everyone is prohibited from burning forests. In line with that, based on Article 69 Paragraph (1) Letter h of Law Number 32 of 2009 it is stated that everyone is prohibited from clearing land by burning. However, in 2019 there will still be forest and land fires in District of Indragiri Hilir, Riau Province covering an area of approximately 827 hectares. The implementation of Law Number 41 of 1999 and Law Number 32 of 2009 concerning forest and land fires in District of Indragiri Hilir hasn't run as expected. Burning forests and land is a crime. Law enforcement against forest and land fires in District of Indragiri Hilir based on Article 78 Paragraph (3) of Law Number 41 of 1999 states that anyone who intentionally burns a forest can be threatened with a maximum of 15 years imprisonment and a maximum fine IDR 5,000,000,000. Pursuant to Article 108 of Law Number 32 of 2009 it is also emphasized that every person who burns a land shall be sentenced to a minimum imprisonment of 3 years and a maximum of 10 years, and a fine of at least IDR 3,000,000,000 and a maximum of IDR 10,000,000,000.

Keyword: Forest and Land Fires, Law, Law Enforcement. 


\section{Introduction}

Forest is an ecosystem unit in the form of a vast expanse of land containing biological natural resources which is dominated by trees in natural environment which cannot be separated from one another [1]. Forest as a gift and mandate from God Almighty that is bestowed upon the Indonesian people is a priceless natural wealth.

Forests, in addition to being a major element of the human life support system, are also the basic capital of national development that have tangible benefits, both ecological benefits, socio-cultural benefits, and economic benefits. Therefore, the utilization must be done in a planned, rational, optimal, and responsible manner in accordance with the carrying capacity and attention to the preservation of environmental functions and balance to support forest management and sustainable forestry development for the people's welfare.

Article 33 Paragraph (3) The 1945 Constitution of the Republic of Indonesia states that the earth, water and natural resources contained therein are controlled by the state and used for the greatest prosperity of the people. In order to obtain optimal benefits from the forest for the welfare of the people, then in principle the forest can be utilized by taking into account its nature, characteristics, and vulnerability and it isn't justified to change the main functions of the forest, namely the function of conservation, protection function, and production function [2]. Forests are one of Indonesia's natural resource wealth which must be preserved in order to be passed on from generation to generation. However, routine fires in Indonesia have destroyed forests.

Forest fires aren't a rare phenomenon in Indonesia, especially in Riau Province. In fact, fires also occur on small lands in community villages. Every year there are forest and land fires routinely in Riau Province. Forests and burnt land cause air pollution in the form of smog that can damage health, even the smog spread to Malaysia and Singapore.

Based on the literature research conducted, researchers obtained data from the National Disaster Management Agency that in 2019 there were 75,871 hectares of forest and land fires in Riau Province. In fact, the forest fire that occurred in Riau Province received serious attention from the President so that Riau Province was visited by President Joko Widodo on September 17, 2019.

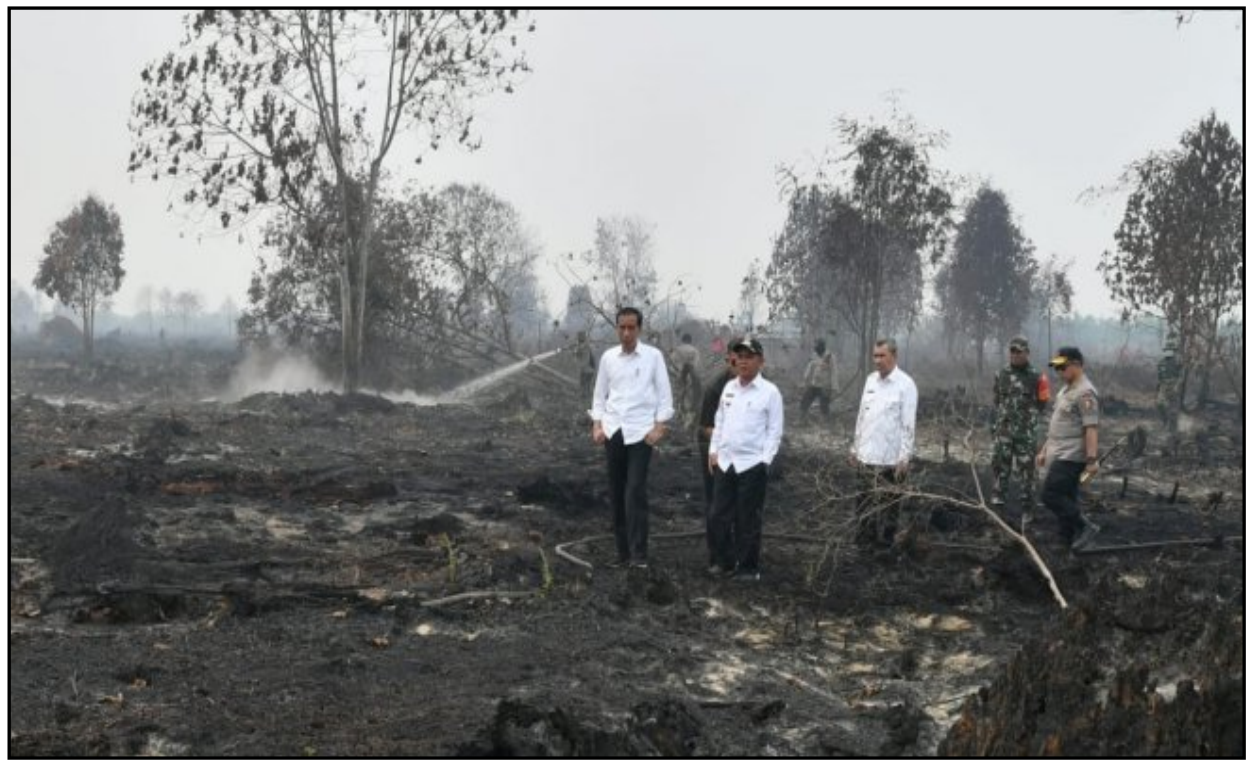

Figure 1. Photo of President Joko Widodo accompanied by Riau Governor Syamsuar directly observing location of forest fires in Riau Province in 2019 
Based on Article 50 Paragraph (3) Letter d of the Law Number 41 of 1999 concerning Forestry it is stated that everyone is prohibited from burning forests. In line with that, based on Article 69 Paragraph (1) Letter h of the Law Number 32 of 2009 concerning Environmental Protection and Management it is stated that everyone is prohibited from clearing land by burning.

From the results of observations of research conducted in District of Indragiri Hilir, Riau Province, researchers obtained information from the Regional Disaster Management Agency of District of Indragiri Hilir that in 2019 forest and land fires occurred in District of Indragiri Hilir Regency covering an area of approximately 827 hectares.

From the introduction explained above, the formulation of the problems that will be discussed in this research are as follows:

1. How is law enforcement of forest and land fire crimes in District of Indragiri Hilir, Riau Province?

2. What is the role of local government in preventing forest and land fires in District Indragiri Hilir, Riau Province?

\section{Research Methodology}

Legal research is a scientific activity that is based on certain methods, systematics, and thoughts that aim to study one or several specific legal phenomena by analyzing them [3]. The method used in this research is socio-legal research. Socio-legal research is a research conducted by explaining the implementation of laws and regulations on problems in society [4].

Source of data used in this research are primary data and secondary data. Primary data is data obtained directly from observations and interviews at the research location; while secondary data is data obtained from scientific journals, legal literature, and statutory regulations. Respondents in this research were the Regional Disaster Management Agency of District of Indragiri Hilir and the Criminal Investigation Unit of the District Police of Indragiri Hilir. Data collection techniques used in this research were observation, interviews, and literature study. The data analysis technique used in this study is qualitative analysis.

\section{Discussions}

The forest is one of the riches of Indonesia's natural resources that can be utilized in everyday life. Therefore, forests must be preserved so that they can be passed on from generation to generation. In line with that, according to Article 50 Paragraph (3) Letter d of the Law Number 41 of 1999 concerning Forestry it is stated that everyone is prohibited from burning forests. Based on Article 69 Paragraph (1) Letter h of the Law Number 32 of 2009 concerning Environmental Protection and Management also stressed that everyone is prohibited from clearing land by burning. These provisions can be interpreted that although forests can be used in everyday life, but every person is prohibited from burning forests and land to obtain benefits so that forest sustainability is maintained.

The implementation of the Law Number 41 of 1999 concerning Forestry and the Law Number 32 of 2009 concerning Environmental Protection and Management of forest and land fires in District of Indragiri Hilir, Riau Province hasn't run as expected. This is because in 2019 there were still forest and land fires in District of Indragiri Hilir Regency, Riau Province. The Regional Disaster Management Agency of District of Indragiri Hilir said that in 2019 there was a forest and land fire in the District of Indragiri Hilir covering an area of approximately 827 hectares.

Laws and regulations in Indonesia actually exclude that the act of burning forests is permissible by considering local wisdom [5]. Article 69 Paragraph (2) of the Law Number 32 of 2009 concerning Environmental Protection and Management states that the provisions stipulating that every person is prohibited from clearing land by burning as regulated in Article 69 Paragraph (1) letter h of that law must pay close attention to local wisdom in their respective regions.

The capability of the Riau Provincial Government in controlling forest fires hasn't been effective because it is only directed at the process of suppressing the burning forest in order to prevent smoke haze. The Riau Provincial Government has yet to find an ideal solution to prevent routine forest fires that occur every year. In addition, the budget allocation of funds provided for handling forest fires is limited so the Riau Provincial Government must wait for financial assistance and equipment from the central government. With a vast expanse of peat forest, the Riau Provincial Government should allocate a large budget to anticipate forest fires, especially in the dry season [6]. 
The obstacles in the implementation of the Law Number 41 of 1999 concerning Forestry and the Law Number 32 of 2009 concerning Environmental Protection and Management of forest and land fires in District of Indragiri Hilir, Riau Province, is still a lack of public understanding of the benefits of forests and lands for the long term. Most people only assume that forests and lands are one of the riches of natural resources that must be managed to improve their economy at that time, without considering that forests are the lungs of the world as a producer of fresh air that is good for human health and is useful for balancing global climate conditions, so the forest must be preserved and bequeathed to the next generation.

Other obstacles in the implementation of the Law Number 41 of 1999 concerning Forestry and the Law Number 32 of 2009 concerning Environmental Protection and Management of forest and land fires in District of Indragiri Hilir, Riau Province, is still weak law enforcement in fire cases forest and land. This is because despite the Law Number 41 of 1999 concerning Forestry and the Law Number 32 of 2009 concerning Environmental Protection and Management as a legal basis prohibiting everyone from burning forests and land, forest fires and land is still routinely occurring every year in District of Indragiri Hilir, Riau Province.

Burning forests and land is a criminal offense, so that in the Law Number 41 of 1999 concerning Forestry and the Law Number 32 of 2009 concerning Environmental Protection and Management governs strict criminal sanctions for anyone who commits acts criminal for burning forests and land.

In order to realize the effectiveness of the implementation of the Law Number 41 of 1999 concerning Forestry and the Law Number 32 of 2009 concerning Environmental Protection and Management in District of Indragiri Hilir, Riau Province, strict law enforcement is required for those who carry out criminal act of burning forest and land. However, law enforcement cann't work as desired because there are factors that influence the process of law enforcement. Soerjono Soekanto [7] states that there are five factors that influence law enforcement, namely the legal factor itself (the law), the law enforcement factor, the facility factor that supports law enforcement, community factors, and cultural factors. These five factors are closely related because they are the essence of law enforcement and a measure of the effectiveness of law enforcement.

Law Enforcement of Forest and Land Fire Crimes in District of Indragiri Hilir, Riau Province which is based on Article 78 Paragraph (3) of the Law Number 41 of 1999 concerning Forestry affirms that anyone who intentionally burns the forest can be threatened with imprisonment for a maximum of 15 years and a maximum fine of IDR 5,000,000,000. Furthermore, Article 78 Paragraph (4) of the Law Number 41 of 1999 concerning Forestry also affirms that whoever due to his negligence causes the forest to burn may be threatened with a maximum imprisonment of 5 years and a maximum fine of $\mathrm{Rp} 1,500,000,000$.

In addition, if the criminal act of forest burning in District of Indragiri Hilir is carried out by a legal entity or business entity and / or on behalf of a legal entity or business entity, the criminal charges will be imposed on the management of the legal entity or business entity with criminal sanctions as has been confirmed in Article 78 Paragraph (3) of the Law Number 41 of 1999 concerning Forestry above, then criminal sanctions are added by $1 / 3$ (one third) of criminal sanctions in Article 78 Paragraph (3) of the Law Number 41 Year 1999 about the Forestry.

In line with that, based on Article 108 of the Law Number 32 of 2009 concerning Environmental Protection and Management it is emphasized that every person who burns a land shall be sentenced to a minimum of 3 years and a maximum of 10 years, and a fine of no less than IDR 3,000,000,000 and a maximum of IDR 10,000,000,000.

If the criminal act of burning forests and land is carried out by a legal entity or a business entity and / or on behalf of a legal entity or business entity, then the principle of strict liability can be used, that is, the accountability of the perpetrators of the crime for the crime he has committed. The principle of strict liability was once applied by judges in decisions on criminal cases of forest and land burning in Riau Province committed by Adei Plantation Ltd. in 2014 [8].

The Government of Indragiri Hilir Regency can make preventive efforts to minimize forest and land fires by conducting legal counseling to the community regarding the prohibition of burning forests and land based on Law Number 41 of 1999 concerning Forestry and Law Number 32 of 2009 concerning Environmental Protection and Management, criminal sanctions for perpetrators of forest and land fires, and the danger of forest and land fires for life. In order to make the prevention more effective, the Government of Indragiri Hilir Regency can work together with the District Police of 
Indragiri Hilir to provide legal counsel to the community. Strengthening the role of the police can psychologically convince the community that burning forests and land is a criminal offense [9].

In addition, the Government of Indragiri Hilir Regency can increase the role of the community in preserving the surrounding forests. Based on the Law Number 41 of 1999 concerning Forestry it is stated that the community is obliged to participate in maintaining and protecting the forest from disturbance and destruction done by irresponsible people [10]. One form of increasing the role of the community to preserve the forest is the existence of awards from the Government of Indragiri Hilir Regency to the community, both individuals and community groups, if they know and report the perpetrators of the forest fires.

The Government of Indragiri Hilir Regency can also adopt the policy of the Riau Provincial Forest Service to prevent forest and land fires in District of ndragiri Hilir [11]. The policies are:

1. Strengthening forest and land areas according to their functions.

2. Improve forest and land rehabilitation and social forestry.

3. Optimizing forest protection and conservation.

4. Optimizing the use of environmentally friendly forests.

5. Strengthening the institutions and entrepreneurship of the communities surrounding the forest.

6. Enhancing the role of the private forestry sector in development.

\section{Conclusion}

Based on Article 50 Paragraph (3) Letter d of the Law Number 41 of 1999 concerning Forestry it is stated that everyone is prohibited from burning forests. In line with that, based on Article 69 Paragraph (1) Letter h of the Law Number 32 of 2009 concerning Environmental Protection and Management it is stated that everyone is prohibited from clearing land by burning. However, in 2019 there will still be forest and land fires in District of Indragiri Hilir covering an area of approximately 827 hectares. The implementation of the Law Number 41 of 1999 concerning Forestry and the Law Number 32 of 2009 concerning Environmental Protection and Management of forest and land fires in District of Indragiri Hilir hasn't run as expected. Burning forests and land is a crime. Law enforcement of forest and land fire crimes in District of Indragiri Hilir, Riau Province based on Article 78 Paragraph (3) of the Law Number 41 of 1999 concerning Forestry affirms that anyone who intentionally burns the forest can be threatened with a maximum of 15 years imprisonment and a fine a maximum of IDR 5,000,000,000. In line with that, based on Article 108 of the Law Number 32 of 2009 concerning Environmental Protection and Management it is emphasized that every person who burns a land shall be sentenced to a minimum of 3 years and a maximum of 10 years, and a fine of no less than IDR 3,000,000,000 and a maximum of IDR 10,000,000,000.

\section{References}

[1] A. M. Yusuf and M. T. Makarao, Hukum Kehutanan di Indonesia. Jakarta: Rineka Cipta, 2011.

[2] H. S. Salim, Dasar-dasar Hukum Kehutanan. Jakarta: Sinar Grafika, 2013.

[3] S. Soekanto, Pengantar Penelitian Hukum. Jakarta: UI Press, 2007.

[4] Z. Ali, Metode Penelitian Hukum. Jakarta: Sinar Grafika, 2013.

[5] H. E. Dikser, Erdianto, and W. Edorita, "Analisis Yuridis terhadap Pengecualian Pembakaran Lahan dan Hutan Berdasarkan Pasal 69 Ayat (2) Undang-Undang Nomor 32 Tahun 2009 tentang Perlindungan dan Pengelolaan Lingkungan Hidup," Jurnal Online Mahasiswa (JOM) Fakultas Hukum Universitas Riau, vol. 4, no. 2, 2017.

[6] G. Meiwanda, "Kapabilitas Pemerintah Daerah Provinsi Riau; Hambatan dan Tantangan Pengendalian Kebakaran Hutan dan Lahan,” Jurnal Sosial Politik, vol 19, no 3, 2016.

[7] S. Seokanto, Faktor-faktor yang Mempengaruhi Penegakan Hukum. Jakarta: Rajawali Pers, 2013.

[8] E. A. Pandiangan, Erdianto, and L. Diana, "Penerapan Prinsip Strict Liability dalam Pertanggungjawaban Korporasi yang Dianggap Bertanggung Jawab atas Kebakaran Hutan di Provinsi Riau," Jurnal Online Mahasiswa (JOM) Fakultas Hukum Universitas Riau, vol. 3, no. 2, 2016.

[9] Supriadi, Hukum Kehutanan dan Hukum Perkebunan di Indonesia. Jakarta: Sinar Grafika, 2010. 
Rizana.

Law Enforcement of Criminal Forests and Land Fire in Kabupaten Indragiri Hilir, Province of Riau.

International Journal of Law and Public Policy, vol. 2, no. 1, pp. 32-37, March 2020. DOI: 10.36079/lamintang.ijlapp-0201.89

[10] Wartiningsih, Pidana Kehutanan; Keterlibatan dan Pertanggungjawaban Penyelenggara Kebijakan Kehutanan. Malang: Setara Press, Malang, 2019.

[11] A. S. Utama, "Kepercayaan Masyarakat terhadap Penegakan Hukum di Indonesia," Jurnal Ensiklopedia Social Review, vol. 1, no. 3, pp. 306-313, 2019. 